\title{
Characterising Novel Pathways in Testis Determination Using Mouse Genetics
}

\author{
Gwenn-Aël Carré Andy Greenfield \\ Mammalian Genetics Unit, Medical Research Council, Harwell, UK
}

\section{Key Words}

Gonadal development · Knockout mice - Mouse genetics .

Sex reversal · Testis determination

\begin{abstract}
Mammalian sex determination is the process by which the bipotential embryonic genital ridge commits to either the testicular or ovarian fate. The existence of a gonad primordium with 2 possible developmental outcomes, depending on the presence or absence of the $Y$ chromosome, remains a fascinating paradigm for examining the manner in which genes cooperate to establish cell fate and regulate differentiation. Development of the mouse gonad offers a unique model for the investigation of sex determination, characterised by powerful transgenic, genomic and other experimental resources for the study of the molecular control of organogenesis. This review focuses on recent progress in our understanding of mouse testis determination, with an emphasis on multi-locus studies of mutant alleles aimed at constructing pathways of interacting gene products. Studies in 2 broad areas have been especially revealing: (i) identification of pathways required for the appropriate expression of Sry, and (ii) characterisation of the antagonistic interactions
\end{abstract}

\begin{tabular}{ll}
\hline KARGER & $\begin{array}{l}\text { ( ) 2014 S. Karger AG, Basel } \\
1661-5425 / 14 / 0085-0199 \$ 39.50 / 0\end{array}$ \\
$\begin{array}{l}\text { E-Mail karger@karger.com } \\
\text { www.karger.com/sxd }\end{array}$ & $\begin{array}{l}\text { This is an Open Access article licensed under the terms of the } \\
\text { Creative Commons Attribution-NonCommercial 3.0 Un- } \\
\text { ported license (CC BY-NC) (www.karger.com/OA-license), } \\
\text { applicable to the online version of the article only. Distribu- } \\
\text { tion permitted for non-commercial purposes only. }\end{array}$
\end{tabular}

between the core testis- (SRY-SOX9-FGF9) and ovary(RSPO1-WNT4-CTNNB1-FOXL2) determining gene regulatory networks. We discuss these advances with an eye on emerging themes in mammalian sex determination.

(c) 2014 S. Karger AG, Basel

The study of cell fate determination is of paramount importance in developmental biology, not least given the current imperative to rationally manipulate the fate of stem cells in vitro for therapeutic applications in medicine. The mammalian gonad is unique in being bipotential: cell lineages of the early gonad respond to extrinsic and intrinsic signals to commit to one of 2 organogenetic fates: testis or ovary. This bipotentiality, its genomic, epigenomic and proteomic basis, is likely to shed much light on our understanding of the molecular underpinnings of lineage commitment and differentiation. The mouse is a powerful tool in experimental developmental biology because of the ease with which its genome can be manipulated and the consequences examined. Much progress has been made in recent years in identifying key molecules that function in the commitment to testis and ovary development in mammals [e.g. reviewed in Jakob

Dr. Andy Greenfield

MRC Mammalian Genetics Unit Harwell, Oxfordshire OX11 0RD (UK)

E-Mail a.greenfield@har.mrc.ac.uk 
and Lovell-Badge, 2011; Quinn and Koopman, 2012; Warr and Greenfield, 2012; Ono and Harley, 2013]. One theme that has emerged by studying the consequences of gene ablation in the mouse is the antagonism that exists between these 2 developmental pathways, from embryo to adult. In this review, we will concentrate on recent progress in our understanding of embryonic testis determination afforded by the study of mouse mutants and detailed phenotypic analyses. In particular, it focuses on multi-locus studies and the attempts to construct developmental pathways from such data, both upstream and downstream of activity of the Y-chromosomal testis-determining gene, Sry, in the gonadal soma.

\section{Regulating Sry Expression}

The Y-linked gene SRY is possibly one of the most enigmatic in the mammalian genome. Its transcript is so rare that it was not detectable in conventional cDNA libraries when its structure in the genital ridge was first investigated; and its protein product, an HMG-box transcription factor, underpins sex determination in most mammals but is not highly conserved and lacked any established target genes in vivo for almost 20 years [Whitfield et al., 1993; Hacker et al., 1995; Jeske et al., 1995; Hiramatsu et al., 2008; Sekido and Lovell-Badge, 2008; Kashimada and Koopman, 2010]. Most intriguingly, its expression is so transient in the mouse gonad that it is detectable for just a handful of hours in a given gonadal somatic cell [Sekido et al., 2004; Wilhelm et al., 2005; Hiramatsu et al., 2008]. Although a number of transcription factors have been implicated in the control of Sry expression [reviewed in Sekido and Lovell-Badge, 2009; Kashimada and Koopman, 2010; Warr and Greenfield, 2012], the molecular basis of this remarkably dynamic expression profile, at the cellular and tissue level, is still a matter of great interest and considerable ignorance. Recent studies are, however, beginning to shed more light on this topic (see overview in fig. 1), and some key Sry regulators are discussed below.

\section{CBX2: A Link between Epigenetics and Sex}

\section{Determination}

CBX2 (also known as M33) is a polycomb group (PcG) protein found in the polycomb-repressive complex 1 (PRC1).PRC1 acts to control gene expression during cellfate specification and differentiation through chromatin modifications, although it is unclear whether the underlying mechanism involves repression of transcriptional

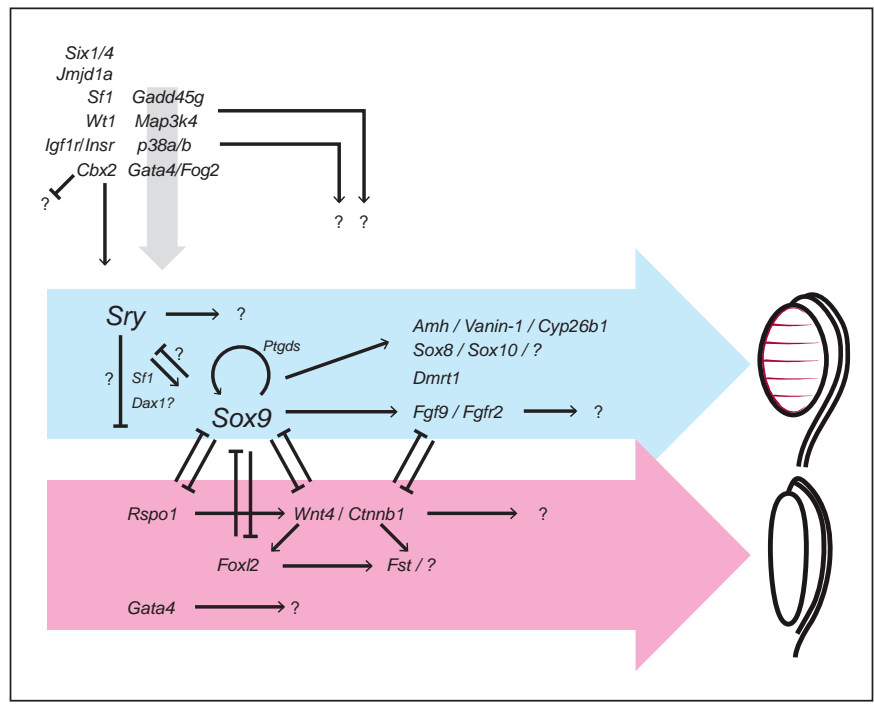

Fig. 1. The mouse testis- and ovary-determining pathways and their mutual antagonism. Genes required for normal Sry expression are shown in the top left, including a GADD45 $\gamma / \mathrm{MAP} 3 \mathrm{~K} 4 /$ p38/GATA4 pathway (grey arrow). Within the large blue arrow are shown the core testis-determining genes Sry, Sox9, Fgf9 and Fgfr 2 and their positive (arrow) or negative (hammered line) interactions. These negative (inhibitory) interactions are almost exclusively with elements of the ovary-determining pathway of Rspo1, Wnt4/ $\beta$-catenin and Foxl2 (large pink arrow), which themselves inhibit the testis-determining genes, primarily Sox9. The existence of possible additional targets, or uncertainty concerning an interaction, is shown by a question mark next to an arrow or hammered line. Arrows and hammered lines do not necessarily indicate a direct interaction between the named genes/proteins.

machinery or regulation of chromatin structure [Simon and Kingston, 2009]. CBX proteins are thought to mediate the recognition of methylated histones by $\mathrm{PRC1}$ via their conserved chromodomains, though other molecular interactions and roles are reported [Blus et al., 2011]. Embryos lacking $C b \times 2$ have previously been reported to exhibit XY gonadal sex reversal, thereby providing a link between PcG-mediated control of gene expression and testis determination [Katoh-Fukui et al., 1998].

A recent publication describes experiments aimed at analysing the phenotypic abnormalities in $C b \times 2$ knockout gonads in further detail [Katoh-Fukui et al., 2012]. Firstly, the authors show that Sry expression is almost undetectable in XY Cbx2-deficient gonads at $11.5 \mathrm{dpc}$. Secondly, they report that reduced proliferation of mesenchymal cells likely causes gonadal hypoplasia in the Cbx2 knockout embryos. Finally, they describe the use of transgenic rescue experiments in which forced gonadal expres- 
sion of Sry and Sox 9 from heterologous promoters is sufficient to rescue sex reversal in Cbx2-deficient XY gonads, though hypoplasia persists. These data indicate that CBX2 likely functions upstream of the regulation of Sry expression and also suggest that any links between cell proliferation, growth and the likelihood of testis determination are complex. Interestingly, forced expression of Sry did not induce testis development in XX Cbx2 knockout gonads, despite the near normal expression levels of SRY in these gonads at $11.5 \mathrm{dpc}$ detected by immunohistochemistry. The mechanistic basis of this phenomenon remains unclear.

The authors were unable to establish a direct link between CBX2 and Sry expression by using chromatin immunoprecipitation (ChIP) to detect occupancy of putative Sry regulatory regions by $\mathrm{CBX} 2$ protein; but neither direct nor indirect effects have been excluded. It also remains unclear whether CBX2 is acting to activate or silence gene expression at target loci during testis determination. Nevertheless, the role of CBX2 in regulating Sry expression in mouse, and possibly in humans [BiasonLauber et al., 2009], provides an entry-point into the study of the epigenetic control of gene expression required for testis determination. Such studies will also benefit from insights gained by examining the mechanistic role of PRC1 in coordinating the timing of entry into meiosis of primordial germ cells in XX embryonic gonads [Yokobayashi et al., 2013].

\section{MAPK Signals Are Decisive in Mouse and Human Testis Determination}

The category of known sex-determining proteins has historically been dominated by transcriptions factors, such as SRY and SOX9, and, to a lesser extent, secreted signalling molecules, such as FGF9 and WNT4. Piecing together the molecular pathways that regulate testis and ovary development requires identifying the full panoply of functional classes of proteins, and possibly non-coding RNAs, that participate. Forward genetic screens in the mouse, allied to chemical mutagenesis, are an increasingly important tool for the identification of novel loci regulating specific aspects of phenotype, especially given the relative ease with which causative mutations can be identified with current genomics resources [Bull et al., 2013]. The first demonstration of a role for mitogen-activated protein kinase (MAPK) signal transduction in mammalian sex determination originated with an N-ethyl-N-nitrosourea (ENU)-based, forward genetic screen for mouse loci regulating gonad morphogenesis [Bogani et al., 2009]. Embryos homozygous for the boygirl (byg) mutation, a

Studies of Mammalian Testis

Determination Using Mouse Genetics null allele of the gene encoding the kinase MAP3K4, exhibit XY gonadal sex reversal on the C57BL/6J (B6) background. This sex reversal is associated with dramatic down-regulation of Sry expression at $11.5 \mathrm{dpc}$, resulting in activation of the ovary-determining pathway and ovary formation. However, the cellular defect in the byg/byg $\mathrm{XY}$ gonad was unclear given the ubiquitous expression of Map3k4 and the potential variety of cellular and molecular pathways that might impact on Sry expression [Bradford et al., 2009; Sekido and Lovell-Badge, 2009].

One approach to determining how MAP3K4 signalling operates in testis determination is to search for determinants of MAP3K4 activity: molecules that interact with, and activate, this kinase and offer spatiotemporal specificity to MAPK signalling. Just such an approach resulted in the identification of Gadd45g, an autosomal testis-determining gene that encodes a MAP3K4-interacting protein [Gierl et al., 2012; Warr et al., 2012]. GADD45 $\gamma$ and its paralogs GADD $45 \alpha$ and GADD $45 \beta$ have been implicated in a number of physiological roles, including the cellular stress response and active DNA demethylation [Hollander and Fornace, 2002; Niehrs and Schäfer, 2012; Schäfer et al., 2013]. Moreover, GADD45 $\gamma$ has been shown to associate with and activate MAP3K4 in other contexts and thereby activate MAPK signalling [Chi et al., 2004; Miyake et al., 2007]. Careful expression analysis of Gadd45g revealed a transient but dynamic expression profile in somatic cells of both the XX and XY gonad between 10.5 and $13.5 \mathrm{dpc}$, reminiscent of the spatiotemporal expression profile of Sry itself. Previous analyses of Gadd45g-deficient mice on a mixed genetic background had not revealed any anomalies of development [Hoffmeyer et al., 2001]; however, on both the C57BL/6J [Warr et al., 2012] and C57BL/6N [Gierl et al., 2012] genetic backgrounds, loss of Gadd $45 g$ causes embryonic XY gonadal sex reversal, confirming that both of these B6 substrains are sensitised to disruptions to testis determination. The sex reversal in both cases is characterised by a delay to Sry expression and a consequent reduction in transcript and protein levels at $11.5 \mathrm{dpc}$, suggesting that GADD $45 \gamma$ acts upstream of Sry in the testis-determining pathway.

The association between GADD45 and active DNA demethylation prompted analyses of the reported tissuespecific differentially methylated region (T-DMR) of the Sry proximal promoter [Nishino et al., 2004] in wild-type and mutant gonadal somatic cells: the existence of the TDMR was confirmed, but no appreciable differences in methylation were found between mutant and controls [Gierl et al., 2012; Warr et al., 2012]. These negative data 
do not exclude a role for GADD45 $\gamma$ in demethylation of other regulatory regions of Sry, or of other loci. However, an alternative mechanism was sought for the impact of loss of GADD $45 \gamma$, and its reported role in the activation of MAP3K4 naturally led to an analysis of MAPK signalling. A deficit in the levels of activated (phosphorylated) p38 MAPK was detected in Gadd45g- and Map3k4-deficient gonads at 16-tail somites (around $11.25 \mathrm{dpc}$ ), suggesting a role for this kinase in testis determination. This was established, firstly, by the use of chemical antagonists and agonists of p38 MAPK signalling in ex vivo models of testis development [Gierl et al., 2012]; secondly, conditional gene targeting showed that loss of both the p38a and $\mathrm{p} 38 \mathrm{~b}$ MAPK isoforms resulted in XY gonadal sex reversal in vivo, again associated with reduction in Sry levels [Warr et al., 2012]. Moreover, phosphorylation of the known Sry transcriptional regulator and MAPK target, GATA4, was also reduced in mutant gonads, suggesting a role for a GADD45 $\gamma / \mathrm{MAP} 3 \mathrm{~K} 4 / \mathrm{p} 38$ pathway in activating GATA4 and thereby initiating timely expression of Sry.

It has been estimated that MAPKs may have around 200-300 substrates each [Cuadrado and Nebreda, 2010], so the identification of additional bona fide targets of p38 MAPK signalling in the developing gonad is likely to be important for our understanding of signal integration during testis determination. p38 MAPKs have emerged as important modulators of gene expression through their recruitment to chromatin and regulation of chromatin modifiers and remodellers [Lluis et al., 2006; Cuadrado et al., 2010; Ferreiro et al., 2010]. Notably, the PcG protein RNF2, involved in chromatin remodelling, is thought to be a substrate of p38 MAPK [Rao et al., 2009]. Given the role of CBX2 and GADD 45 proteins in epigenetic modulation, and the fact that MAP3K4 can activate the histone acetyltransferase, CBP, in trophoblast stem cells [Abell et al., 2011], it is probable that epigenomic profiling of somatic cells during sex determination, in both mutant and wild-type gonads, will be a fruitful area of future study. Moreover, the role of non-coding RNAs in gonad development, widely implicated in epigenetic regulation, remains to be determined [Chen et al., 2012]. The dynamic expression profiles of genes such as Gadd45g and Sry require some mechanistic explanation at the level of chromatin; however, this will require the genome-wide epigenomic analysis of very limiting amounts of tissue from multiple embryonic stages, e.g. somatic cells isolated from the XY and XX mouse gonad between 10.5 and $14.5 \mathrm{dpc}$. The efficiency of standard technologies such as ChIP will need to improve for this to be possible, although progress here is apparent [ $\mathrm{Ng}$ et al., 2013]. Alternatively, the promise of in vitro reprogramming may yet allow the routine production of large numbers of cells with properties very close to those of embryonic pre-Sertoli/Sertoli cells [Buganim et al., 2012]. Substitution of a cell line model or analysis of other non-limiting tissues, while permitting straightforward use of the available technology, is unlikely to yield data that are as relevant to our understanding of sex determination in vivo.

The identification of MAP $3 K 1$ mutations in familial and sporadic instances of 46,XY disorders of sex development (DSD), including cases of $46, \mathrm{XY}$ complete gonadal dysgenesis (sex reversal), suggests some role for MAPK signalling in human testis determination [Pearlman et al., 2010]. No definitive MAP3K1 null alleles causing 46,XY DSD have been reported, i.e. stop-codons causing premature truncation of the MAP3K1 polypeptide. Moreover, Map $3 k 1$ is not required for mouse testis determination [Warr et al., 2011]. Together, these observations suggest that sex-reversing MAP $3 K 1$ mutations may be gain-offunction alleles, somehow disrupting MAPK signalling at a crucial phase of human testis determination. This could be tested by introduction of such mutations into the mouse genome. Of course, which MAPKs are actually required for human testis determination, and at which stages, remains unclear and requires the identification of lossof-function alleles in cases of 46,XY DSD. Nevertheless, it is our prediction that the genetic pathway leading to $S R Y$ activation may provide a promising source of candidate genes that, if mutated appropriately, lead to $46, \mathrm{XY}$ DSD in the human population.

\section{Insulin and IGF1 Receptors and Sry Expression}

A previous study reported XY gonadal sex reversal in triple knockout embryos lacking insulin receptor (INSR), IGF type I receptor (IGF1R) and insulin receptor-related receptor (IRR) [Nef et al., 2003]. This sex reversal was attributed to a reduction in Sry expression. A recent followup study has now demonstrated that loss of only INSR and IGF1R is sufficient to cause XY gonadal sex reversal, in addition to growth retardation [Pitetti et al., 2013]. This sex reversal is characterised by a dramatic loss of Sry expression at $11.5 \mathrm{dpc}$, although transcripts are detectable by $12.5 \mathrm{dpc}$, indicating an actual delay in expression. One interesting aspect of this phenotype is the delay in ovarian differentiation observed in both XY and XX mutant gonads: key ovarian markers, such as FOXL2 and SCP3, are not detectable until $16.5 \mathrm{dpc}$. What is the basis of this delay in differentiation? Expression profiling of SF1-posi- 
tive cells from mutant and wild-type gonads at $11.5 \mathrm{dpc}$ revealed significant down-regulation in mutant cells of a number of genes that are normally expressed in a sexspecific fashion later during testis and ovary development. This down-regulation was observed in both XY and XX mutant cells. It may be that insulin/IGF1 signalling is required early in gonad development to initiate expression of both testis- and ovary-determining gene networks: down-regulation of these in mutant gonads may contribute to the delay in activating the ovarian pathway. Growth retardation and loss of SF1-positive cells in mutant gonads may reflect a global effect of ablating insulin/IGF signalling; the contribution made by cell proliferation defects to XY sex reversal and the molecular mechanisms by which sex-determining gene expression, including Sry, is controlled by this signalling pathway remain to be determined.

\section{Sex Determination: Genetic Antagonism, Redundancy and Complexity}

The phenomenon of XY gonadal sex reversal caused by single-gene mutation reveals that some genes are acting not just to promote testis development but also to suppress the ovarian fate - potentially playing an exclusively inhibitory role. Recent studies of mouse mutants, especially those combining loss-of-function alleles at more than one locus, reveal how genetic interactions and pathways are often more complex, and potentially context-specific, than originally conceived from the analysis of single-gene defects.

Testis Differentiation in the Absence of SRY and SOX9 SOX 9 is a paradigmatic sex-determining gene in mice and humans: it is necessary for testis development on an XY genetic background [Foster et al., 1994; Wagner et al., 1994; Chaboissier et al., 2004; Barrionuevo et al., 2006; Lavery et al., 2011] and sufficient to induce testis development in an XX embryo [Huang et al., 1999; Bishop et al., 2000; Vidal et al., 2001; Cox et al., 2011]. Its protein product is an HMG box-containing transcription factor with potentially numerous targets, some of which are required for testis determination and some, presumably, for more specific aspects of Sertoli cell differentiation. Analysis of Sox9-deficient XY gonads generated by conditional gene targeting reveals gonadal sex reversal in fetal [Chaboissier et al., 2004; Barrionuevo et al., 2006; Lavery et al., 2011] and adult mice [Lavery et al., 2011], characterised by loss of testicular markers and inappropriate expression

Studies of Mammalian Testis

Determination Using Mouse Genetics of pro-ovary genes such as Wnt4. These data indicate a role for SOX9 in inhibiting the ovarian pathway of development, although the molecular basis of this remains unclear. The canonical WNT/ $\beta$-catenin signalling pathway promotes ovary differentiation [Vainio et al., 1999; Maatouk et al., 2008] and SOX9 may directly inhibit $\beta$-catenin activity, as it does during chondrogenesis [Akiyama et al., 2004; Topol et al., 2009]. Alternatively, it may act to inhibit expression of the ovary determinant, Foxl2 [Wilhelm et al., 2009; Georg et al., 2012]. Interestingly, after testis determination, SOX9 appears to be dispensable for testis cord differentiation due to the presence of the related protein, $\mathrm{SOX} 8$, revealing how functional redundancy can complicate interpretation of normal gene function [Barrionuevo et al., 2009; Georg et al., 2012].

A recent study shows that the mutually antagonistic testis- and ovary-determining pathways can be jointly disrupted by gene inactivation in such a way that testis development is possible even in the absence of the master testis-determining genes, Sry and Sox9 [Lavery et al., 2012]. RSPO1 promotes ovary development through its activation of WNT/ $\beta$-catenin signalling [Tomizuka et al., 2008]. Loss of RSPO1 causes delayed, partial female-tomale gonadal sex reversal in XX mice, associated with upregulation of Sox 9 expression around birth [Chassot et al., 2008]. One prediction from these data is that, given the putative role of SOX9 in inducing testis development in RSPO1-deficient XX mice, removal of both RSPO1, a key ovary determinant, and SOX9, a reliable testis inducer, would result in failure of both ovary and testis differentiation. However, XX fetuses lacking both RSPO1 and SOX9, in addition to SRY, exhibit delayed development of ovotestes and hypoplastic testes [Lavery et al., 2012]. What might account for this? Expression profiling revealed activation of expression of both Sox10 (at P0) and Sox8 (at P12) in double knockout gonads. Both genes belong with Sox9 in the SoxE gene family and are associated with testis development; indeed, ectopic expression of Sox10 in XX embryos can induce testis differentiation [Polanco et al., 2010]. This Sox8/Sox10 gene activation in Rspo1/Sox9 double knockout gonads implies inhibition of expression of these genes by either SOX9 or RSPO1 in normal circumstances; most likely RSPO1, given that it promotes ovary differentiation. Finally, removal of both Sox9 and Sox8 results in failure of normal testis cord differentiation after the sex determination stage and progressive transdifferentiation of mutant Sertoli cells to an ovarian-like fate, associated with strong down-regulation of Sox10 expression [Barrionuevo et al., 2009; Georg et al., 2012]. Thus, SOX8 and SOX9 are required for Sox10 ex- 
pression in the fetal testis, but the absence of Rspo1 presumably obviates this requirement for SOX9. The molecular basis of these genetic relationships needs further investigation.

Such circumstances tell us much about how sex-determining gene regulatory networks respond robustly to catastrophic genetic insult and will no doubt shed light on the aetiology and pathology of some cases of 46,XY DSD in humans. Of course, the phenotypic consequences of gene ablation experiments reflect the response of the whole mouse genome to the insults: the role of mutationdependent, strain-specific modifiers of phenotype has been reported before in the context of Sox gene function [Hosking et al., 2009]. It appears that the sex-determining mechanism, like others, has evolved so as to permit gonadogenesis to proceed even in the absence of proteins that are known to function under normal circumstances. This is evidence of the strong canalisation of the sex-determining mechanism: either ovary or testis development is a required outcome. Formation of some intermediate tissue is, in an evolutionary sense, to be avoided. Delayed commitment to a specific cell fate, as reported in one other mutant discussed above, is associated to varying degrees with the deletion of the Foxl2 and Dmrt1 genes in adult mouse gonads that ultimately results in somatic cell reprogramming [Uhlenhaut et al., 2009; Matson et al., 2011]. In the case of Sertoli cell-specific deletion of Dmrt1, a switch occurs from predominantly SOX9-positive Sertoli cells at P7 to predominantly FOXL2-positive cells by P28: the testis-to-ovary reprogramming is extended over a significant period of time [Matson et al., 2011]. This may reflect the complexity of in vivo cellular reprogramming that occurs in these abnormal genetic contexts when certain gene products that are normally expressed in a cell lineage at a particular stage do not appear, or suddenly disappear. These delays are perhaps reminiscent of the time taken to reprogram somatic cells into pluripotential stem cells in vitro [Muraro et al., 2013]. Future studies will be important to address why sex reversal is still an outcome of such adult gene deletions, as opposed to the adoption of some other cell fate, and how similar the genomic and transcriptomic contexts are of adult and embryonic gonadal cell lineages. The relationship between gonad reprogramming and late-onset disease will also be important to examine.

\section{FGF Signalling: Positive or Negative Role?}

FGF signalling was first shown to play an important role in testis determination when XY gonadal sex reversal of Fgf9-deficient mouse embryos was reported [Colvin et al., 2001]. Loss of Fgf9 in XY gonads results in loss of testicular markers and inappropriate expression of ovarydetermining genes such as Wnt4 [Kim et al., 2006]. The gonadal receptor for FGF9, FGFR2, has an established role in testis determination based on data from conditional gene ablation experiments. Whilst such analyses are beset by incomplete deletion of floxed alleles, often based on the variable performance and specificity of Cre deleter lines, 2 separate studies reported defects in testis determination upon gonadal deletion of $F g f r 2$ using distinct Cre lines [Kim et al., 2007; Bagheri-Fam et al., 2008].

A reduction in the abundance of Sox 9 transcripts in Fgf9 homozygous mutant gonads suggested a role for FGF9 in regulating Sox9 expression [Colvin et al., 2001]. Further studies revealed that initial up-regulation of Sox 9 at 11.5 dpc occurred normally in Fgf9 homozygous mutant gonads; however, SOX9 was not detectable at 12.5 $\mathrm{dpc}$, indicating a role for FGF9 in maintenance of Sox9 expression [Kim et al., 2006]. In contrast, Sry expression at $11.5 \mathrm{dpc}$ was unaffected in Fgf9-deficient gonads. The relationship between Sox 9 and $F g f 9$ was shown to be one of mutual dependence, since in gonads lacking Sox9 generated by conditional gene targeting, Fgf 9 expression was greatly reduced or absent [Kim et al., 2006].

Whilst initially interpreted as a genetic interaction characterised by positive feedback, recent data suggest a more complex interaction between Fgf9 and Sox9, involving Wnt4 [Jameson et al., 2012a]. Given that Wnt4 expression is activated in Fgf9- and Fgfr2-deficient XY gonads, there was a possibility that deletion of Wnt4 would rescue sex reversal in these mutants. Generation of mice and embryos lacking both Fgf9 and Wnt4 (as well as Fgfr2 and $W n t 4)$ revealed that testis development could proceed in the absence of these FGF and WNT signalling components. Thus, while FGF9 signalling is required to inhibit the ovarian genetic pathway (in particular the WNT pathway) in XY gonads, these double knockouts suggest that it does not act directly or positively to maintain SOX9 expression and control other aspects of testicular morphogenesis. As in the case of testis development in the absence of SRY and SOX9, these data do not contradict the known role for FGF9/FGFR2 in testis determination; they show that the requirement for this role is dependent on the activity of other genes, in this case, Wnt4. Given the examples discussed earlier, in which related genes are up-regulated in some gene knockouts, thereby potentially offering a mechanistic explanation for sex determination in the absence of key genes, it would be interesting to know whether, for example, alternative FGF ligands are activated in Fgf9/Wnt4 double knock- 
outs. In this context, it is noteworthy that $\mathrm{Fg} f 10$ is expressed in the XY and XX mouse gonad at $11.5 \mathrm{dpc}$ [Hiramatsu et al., 2010]. These data also reveal how difficult it is to infer the structure of pathways from genetic analyses before the phenotypic consequences of all combinations of mutant loci have been analysed. Figure 1 depicts a possible pathway relating SRY/SOX9/FGF9 functions and ovary-determining genes. Finally, it is interesting to note that an essentially negative role for FGF9 in suppressing canonical WNT signalling would suggest that its paracrine role in rapidly spreading the testis-determining signal from its initial source in the centre of the gonad to the poles [Hiramatsu et al., 2010] is one designed to extinguish an ovarian fate which the gonadal soma may otherwise be primed to adopt [Jameson et al., 2012b].

\section{Conclusion}

It is likely that future progress in sex determination research will involve the delineation of ever more elaborate pathways in testis and ovary development, with more antagonistic interactions evident between them. This will necessitate further investigation of the remarkable and unexpected plasticity of cell identity in the adult testis, which requires DMRT1, and no doubt other pro-testis genes, for its maintenance [Matson et al., 2011]. Study of epigenomic mechanisms that underlie dynamic expression patterns and detailed characterization of mutual antagonism at the molecular level will also be central. Given the focus on the circuitry of gene regulation that is apparent in current research, it is also probable that the connections between the whirl of transcription factors and the expression of other functional classes of protein will be belatedly established. In this way, details of the molecular basis of cellular differentiation during later gonad morphogenesis will emerge as part of a coherent picture of mammalian gonad development and function, with mouse genetics, genomics and phenomics as integral parts of the story of its elaboration.

\section{Acknowledgements}

The authors apologise to colleagues for any published data not discussed in this review. Such omissions are due to space constraints. We also thank Steve Thomas for assistance in the production of figure 1 and other members of the Greenfield laboratory at Harwell for useful comments on the manuscript.

\section{References}

Abell AN, Jordan NV, Huang W, Prat A, Midland $\mathrm{AA}$, et al: MAP3K4/CBP-regulated $\mathrm{H} 2 \mathrm{~B}$ acetylation controls epithelial-mesenchymal transition in trophoblast stem cells. Cell Stem Cell 8:525-537 (2011).

-Akiyama H, Lyons JP, Mori-Akiyama Y, Yang X, Zhang R, et al: Interactions between Sox 9 and beta-catenin control chondrocyte differentiation. Genes Dev 18:1072-1087 (2004).

Bagheri-Fam S, Sim H, Bernard P, Jayakody I, Taketo MM, et al: Loss of Fgfr2 leads to partial XY sex reversal. Dev Biol 314:71-83 (2008).

-Barrionuevo F, Bagheri-Fam S, Klattig J, Kist R, Taketo MM, et al: Homozygous inactivation of Sox 9 causes complete XY sex reversal in mice. Biol Reprod 74:195-201 (2006).

-Barrionuevo F, Georg I, Scherthan H, Lecureuil C, Guillou F, et al: Testis cord differentiation after the sex determination stage is independent of Sox 9 but fails in the combined absence of Sox9 and Sox8. Dev Biol 327:301-312 (2009).

-Biason-Lauber A, Konrad D, Meyer M, DeBeaufort C, Schoenle EJ: Ovaries and female phenotype in a girl with 46,XY karyotype and mutations in the $C B X 2$ gene. Am J Hum Genet 84:658-663 (2009).
Bishop CE, Whitworth DJ, Qin Y, Agoulnik AI, Agoulnik IU, et al: A transgenic insertion upstream of Sox9 is associated with dominant XX sex reversal in the mouse. Nat Genet 26: 490-494 (2000).

Blus BJ, Wiggins K, Khorasanizadeh S: Epigenetic virtues of chromodomains. Crit Rev Biochem Mol Biol 46:507-526 (2011).

Bogani D, Siggers P, Brixey R, Warr N, Beddow S: Loss of mitogen-activated protein kinase kinase kinase 4 (MAP3K4) reveals a requirement for MAPK signalling in mouse sex determination. PLoS Biol 7:e1000196 (2009).

Bradford ST, Wilhelm D, Bandiera R, Vidal V, Schedl A, Koopman P: A cell-autonomous role for WT1 in regulating Sry in vivo. Hum Mol Genet 18:3429-3438 (2009).

Buganim Y, Itskovich E, Hu YC, Cheng AW, Ganz $\mathrm{K}$, et al: Direct reprogramming of fibroblasts into embryonic Sertoli-like cells by defined factors. Cell Stem Cell 11:373-386 (2012).

- Bull KR, Rimmer AJ, Siggs OM, Miosge LA, Roots CM, et al: Unlocking the bottleneck in forward genetics using whole-genome sequencing and identity by descent to isolate causative mutations. PLoS Genet 9:e1003219 (2013).
Chaboissier MC, Kobayashi A, Vidal VI, Lutzkendorf S, van de Kant HJ, et al: Functional analysis of Sox8 and Sox9 during sex determination in the mouse. Development 131:18911901 (2004).

Chassot AA, Ranc F, Gregoire EP, Roepers-Gajadien HL, Taketo MM, et al: Activation of beta-catenin signaling by Rspol controls differentiation of the mammalian ovary. Hum Mol Genet 17:1264-1277 (2008).

-Chen H, Palmer JS, Thiagarajan RD, Dinger ME, Lesieur E, et al: Identification of novel markers of mouse fetal ovary development. PLoS One 7:e41683 (2012).

-Chi H, Lu B, Takekawa M, Davis RJ, Flavell RA: GADD $45 \beta / G A D D 45 \gamma$ and MEKK 4 comprise a genetic pathway mediating STAT4-independent IFN $\gamma$ production in T cells. EMBO J 23:1576-1586 (2004).

-Colvin JS, Green RP, Schmahl J, Capel B, Ornitz DM: Male-to-female sex reversal in mice lacking fibroblast growth factor 9. Cell 104:875889 (2001).

Cox JJ, Willatt L, Homfray T, Woods CG: A SOX9 duplication and familial 46,XX developmental testicular disorder. N Engl J Med 364:9193 (2011).
Studies of Mammalian Testis

Determination Using Mouse Genetics 
Cuadrado A, Nebreda AR: Mechanisms and functions of p38 MAPK signalling. Biochem J 429: 403-417 (2010).

-Cuadrado A, Corrado N, Perdiguero E, Lafarga V, Munoz-Canoves P, Nebreda AR: Essential role of $\mathrm{p} 18^{\text {Hamlet}} / \mathrm{SRCAP}$-mediated histone H2A.Z chromatin incorporation in muscle differentiation. EMBO J 29:2014-2025 (2010).

-Ferreiro I, Barragan M, Gubern A, Ballestar E, Joaquin M, Posas F: The p38 SAPK is recruited to chromatin via its interaction with transcription factors. J Biol Chem 285:3181931828 (2010).

- Foster JW, Dominguez-Steglich MA, Guioli S, Kwok C, Weller PA, et al: Campomelic dysplasia and autosomal sex reversal caused by mutations in an $S R Y$-related gene. Nature 372:525-530 (1994).

Georg I, Barrionuevo F, Wiech T, Scherer G: Sox 9 and Sox 8 are required for basal lamina integrity of testis cords and for suppression of FOXL2 during embryonic testis development in mice. Biol Reprod 87:99 (2012).

-Gierl MS, Gruhn WH, von Seggern A, Maltry N, Niehrs C: GADD45G functions in male sex determination by promoting p38 signaling and Sry expression. Dev Cell 23:1032-1042 (2012).

-Hacker A, Capel B, Goodfellow P, Lovell-Badge R: Expression of Sry, the mouse testis-determining gene. Development 121:1603-1614 (1995).

-Hiramatsu R, Matoba S, Kanai-Azuma M, Tsunekawa N, Katoh-Fukui Y, et al: A critical time window of Sry action in gonadal sex determination in mice. Development 136:129138 (2008).

- Hiramatsu R, Harikae K, Tsunekawa N, Kurohmaru M, Matsuo I, Kanai Y: FGF signaling directs a center-to-pole expansion of tubulogenesis in mouse testis differentiation. Development 137:303-312 (2010).

- Hoffmeyer A, Piekorz R, Moriggl R, Ihle JN: Gadd $45 \gamma$ is dispensable for normal mouse development and T-cell proliferation. Mol Cell Biol 21:3137-3143 (2001).

-Hollander MC, Fornace AJ Jr: Genomic instability, centrosome amplification, cell cycle checkpoints and Gadd45a. Oncogene 21: 6228-6233 (2002).

-Hosking B, Francois M, Wilhelm D, Orsenigo F, Caprini A, et al: Sox7 and Sox17 are strainspecific modifiers of the lymphangiogenic defects caused by Sox18 dysfunction in mice. Development 136:2385-2391 (2009).

-Huang B, Wang S, Ning Y, Lamb AN, Bartley J: Autosomal XX sex reversal caused by duplication of SOX9. Am J Med Genet 87:349-353 (1999).

-Jakob S, Lovell-Badge R: Sex determination and the control of Sox9 expression in mammals. FEBS J 278:1002-1009 (2011).

-Jameson SA, Lin YT, Capel B: Testis development requires the repression of Wnt 4 by Fgf signaling. Dev Biol 370:24-32 (2012a).
Jameson SA, Natarajan A, Cool J, DeFalco T, Maatouk DM, et al: Temporal transcriptional profiling of somatic and germ cells reveals biased lineage priming of sexual fate in the fetal mouse gonad. PLoS Genet 8:e1002575 (2012b).

Jeske YWA, Bowles J, Greenfield A, Koopman P: Expression of a linear Sry transcript in the mouse genital ridge. Nat Genet 10:480-482 (1995).

Kashimada K, Koopman P: Sry: the master switch in mammalian sex determination. Development 137:3921-3930 (2010).

Katoh-Fukui Y, Tsuchiya R, Shiroishi T, Nakahara $\mathrm{Y}$, Hashimoto $\mathrm{N}$, et al: Male-to-female sex reversal in M33 mutant mice. Nature 393: 688-692 (1998).

-Katoh-Fukui Y, Miyabayashi K, Komatsu T, Owaki A, Baba T, et al: Cbx2, a polycomb group gene, is required for Sry gene expression in mice. Endocrinology 153:913-924 (2012).

-Kim Y, Kobayashi A, Sekido R, DiNapoli L, Brennan J, et al: $F g f 9$ and $W n t 4$ act as antagonistic signals to regulate mammalian sex determination. PLoS Biol 4:e187 (2006).

Kim Y, Bingham N, Sekido R, Parker KL, LovellBadge R, Capel B: Fibroblast growth factor receptor 2 regulates proliferation and Sertoli differentiation during male sex determination. Proc Natl Acad Sci USA 104:1655816563 (2007).

-Lavery R, Lardenois A, Ranc-Jianmotamedi F, Pauper E, Gregoire EP, et al: XY Sox 9 embryonic loss-of-function mouse mutants show complete sex reversal and produce partially fertile XY oocytes. Dev Biol 354:111-122 (2011).

Lavery R, Chassot AA, Pauper E, Gregoire EP, Klopfenstein M, et al: Testicular differentiation occurs in absence of R-spondin 1 and Sox 9 in mouse sex reversals. PLoS Genet 8:e1003170 (2012).

Lluis F, Perdiguero E, Nebreda AR, MunozCanoves P: Regulation of skeletal muscle gene expression by p38 MAP kinases. Trends Cell Biol 16:36-44 (2006).

Maatouk DM, DiNapoli L, Alvers A, Parker KL, Taketo MM, Capel B: Stabilization of $\beta$-catenin in XY gonads causes male-to-female sex-reversal. Hum Mol Genet 17:29492955 (2008).

- Matson CK, Murphy MW, Sarver AL, Griswold MD, Bardwell VJ, Zarkower D: DMRT1 prevents female reprogramming in the postnatal mammalian testis. Nature 476:101-104 (2011).

Miyake Z, Takekawa M, Ge Q, Saito H: Activation of MTK1/MEKK4 by GADD45 through induced N-C dissociation and dimerizationmediated trans autophosphorylation of the MTK1 kinase domain. Mol Cell Biol 27:27652776 (2007).

Muraro MJ, Kempe H, Verschure PJ: The dynamics of induced pluripotency and its behavior captured in gene network motifs. Stem Cells 31:838-848 (2013).
Nef S, Verma-Kurvari S, Merenmies J, Vassalli JD, Efstratiadis A, et al: Testis determination requires insulin receptor family function in mice. Nature 426:291-295 (2003).

- Ng JH, Kumar V, Muratani M, Kraus P, Yeo JC, et al: In vivo epigenomic profiling of germ cells reveals germ cell molecular signatures. Dev Cell 24:324-333 (2013).

Niehrs C, Schäfer A: Active DNA demethylation by Gadd 45 and DNA repair. Trends Cell Biol 22:220-227 (2012).

Nishino K, Hattori N, Tanaka S, Shiota K: DNA methylation-mediated control of Sry gene expression in mouse gonadal development. J Biol Chem 279:22306-22313 (2004).

Ono M, Harley VR: Disorders of sex development: new genes, new concepts. Nat Rev Endocrinol 9:79-91 (2013).

- Pearlman A, Loke J, Le Caignec C, White S, Chin L, et al: Mutations in MAP3K1 cause 46,XY disorders of sex development and implicate a common signal transduction pathway in human testis determination. Am J Hum Genet 87:898-904 (2010)

Pitetti JL, Calvel P, Romero Y, Conne B, Truong $\mathrm{V}$, et al: Insulin and IGF1 receptors are essential for XX and $\mathrm{XY}$ gonadal differentiation and adrenal development in mice. PLoS Genet 9:e1003160 (2013).

Polanco JC, Wilhelm D, Davidson TL, Knight D, Koopman P: Sox10 gain-of-function causes $\mathrm{XX}$ sex reversal in mice: implications for human 22q-linked disorders of sex development. Hum Mol Genet 19:506-516 (2010).

Quinn A, Koopman P: The molecular genetics of sex determination and sex reversal in mammals. Semin Reprod Med 30:351-363 (2012).

Rao PS, Satelli A, Zhang S, Srivastava SK, Srivenugopal KS, Rao US: RNF2 is the target for phosphorylation by the p38 MAPK and ERK signaling pathways. Proteomics 9:2776-2787 (2009).

-Schäfer A, Karaulanov E, Stapf U, Doderlein G, Niehrs C: Ing1 functions in DNA demethylation by directing Gadd45a to H3K4me3. Genes Dev 27:261-273 (2013).

- Sekido R, Lovell-Badge R: Sex determination involves synergistic action of SRY and SF1 on a specific Sox9 enhancer. Nature 453:930-934 (2008).

- Sekido R, Lovell-Badge R: Sex determination and SRY: down to a wink and a nudge? Trends Genet 25:19-29 (2009).

- Sekido R, Bar I, Narvaez V, Penny G, LovellBadge R: SOX9 is up-regulated by the transient expression of SRY specifically in Sertoli cell precursors. Dev Biol 274:271-279 (2004).

- Simon JA, Kingston RE: Mechanisms of polycomb gene silencing: knowns and unknowns. Nat Rev Mol Cell Biol 10:697-708 (2009).

-Tomizuka K, Horikoshi K, Kitada R, Sugawara Y, Iba $Y$, et al: R-spondin1 plays an essential role in ovarian development through positively regulating Wnt-4 signaling. Hum Mol Genet 17:1278-1291 (2008). 
Topol L, Chen W, Song H, Day TF, Yang Y: Sox9 inhibits Wnt signaling by promoting betacatenin phosphorylation in the nucleus. J Biol Chem 284:3323-3333 (2009).

Uhlenhaut NH, Jakob S, Anlag K, Eisenberger T, Sekido R, et al: Somatic sex reprogramming of adult ovaries to testes by FOXL2 ablation. Cell 139:1130-1142 (2009).

-Vainio S, Heikkila M, Kispert A, Chin N, McMahon AP: Female development in mammals is regulated by Wnt-4 signalling. Nature 397: 405-409 (1999).

-Vidal VP, Chaboissier MC, de Rooij DG, Schedl A: Sox9 induces testis development in $\mathrm{XX}$ transgenic mice. Nat Genet 28:216-217 (2001).

\section{Note Added in Proof}

Two recent publications reveal even more complexity in the genetic pathways required for Sry expression in the mouse. Firstly, the importance of controlled epigenetic modifications in testis determination is further underlined by the report of $\mathrm{XY}$ gonadal sex reversal in mice lacking the histone demethylase, JMJD1A (KDM3A) [Kuroki et al., 2013]. This report describes the role of JMJD1A in positively regulating Sry expression by demethylation of the inhibitory histone mark, $\mathrm{H} 3 \mathrm{~K} 9 \mathrm{me} 2$, at chro-
Wagner T, Wirth J, Meyer J, Zabel B, Held M, et al: Autosomal sex reversal and campomelic dysplasia are caused by mutations in and around the SRY-related gene SOX9. Cell 79: 1111-1120 (1994).

-Warr N, Greenfield A: The molecular and cellular basis of gonadal sex reversal in mice and humans. Wiley Interdiscip Rev Dev Biol 1:559577 (2012).

Warr N, Bogani D, Siggers P, Brixey R, Tateossian $\mathrm{H}$, et al: Minor abnormalities of testis development in mice lacking the gene encoding the MAPK signalling component, MAP3K1. PLoS One 6:e19572 (2011).

Warr N, Carre GA, Siggers P, Faleato JV, Brixey $\mathrm{R}$, et al: Gadd45y and Map3k4 interactions regulate mouse testis determination via p38 MAPK-mediated control of Sry expression. Dev Cell 23:1020-1031 (2012).
Whitfield LS, Lovell-Badge R, Goodfellow PN: Rapid sequence evolution of the mammalian sex determining gene SRY. Nature 364:713715 (1993).

-Wilhelm D, Martinson F, Bradford S, Wilson MJ, Combes AN, et al: Sertoli cell differentiation is induced both cell-autonomously and through prostaglandin signaling during mammalian sex determination. Dev Biol 287: 111-124 (2005).

Wilhelm D, Washburn LL, Truong V, Fellous M, Eicher EM, Koopman P: Antagonism of the testis- and ovary-determining pathways during ovotestis development in mice. Mech Dev 126:324-336 (2009).

Yokobayashi S, Liang CY, Kohler H, Nestorov P, Liu Z, et al: PRC1 coordinates timing of sexual differentiation of female primordial germ cells. Nature 495:236-240 (2013). matin of the Sry locus. This may be an important step in the deheterochromatinization of this Y-linked locus prior to the recruitment of transcription factors. Secondly, the role of the transcription factors SIX1 and SIX4 in sex determination is demonstrated by XY gonadal sex reversal in embryos lacking both proteins [Fujimoto et al., 2013]. SIX1 and SIX4 are reported to regulate Fog2 ( $\mathrm{ffpm}$ ) expression, which is itself required for expression of Sry.

\section{References}

Fujimoto Y, Tanaka SS, Yamaguchi YL, Kobayashi H, Kuroki S, et al: Homeoproteins Six1 and Six 4 regulate male sex determination and mouse gonadal development. Dev Cell 26:416-430 (2013).

Kuroki S, Matoba S, Akiyoshi M, Matsumura Y, Miyachi $\mathrm{H}$, et al: Epigenetic regulation of mouse sex determination by the histone demethylase Jmjdla. Science 341:1106-1109 (2013).
Studies of Mammalian Testis

Determination Using Mouse Genetics 